\title{
The technique development of non-washing of mineral fertilizers in the soil through the screen formed on the interpolymer complex basis
}

\author{
Nodir Gadaev ${ }^{*}$, Daulet Gulomov, Jumanazar Egamov, Malika Nasirova, and Jaloliddin \\ Norboyev \\ Tashkent Institute of Irrigation and Agricultural Mechanization Engineers, Tashkent, Uzbekistan
}

\begin{abstract}
The problem of global climate change is on the agenda of mankind, not only because of the average annual temperature rise on the planet but also because of changes in the entire geosystem, rising global oceans, melting ice and permanent glaciers, increasing uneven rainfall, changing river flow patterns and climate instability, other changes involved. The world pays special attention to research work to develop technologies for the management and efficient use of water resources. In particular, it is important to conduct research to develop new water-saving irrigation technologies using cheap and chemical, and technical means.
\end{abstract}

\section{Introduction}

As a result of climate change, the area of glaciers in Central Asia has shrunk by about 30 percent over the past 50-60 years. According to forecasts, the volume of glaciers will decrease by 50 percent when the temperature rises to $20{ }^{\circ} \mathrm{C}$ and by 78 percent when heated to $40{ }^{\circ} \mathrm{C}$. According to estimates, by 2050 , water resources in the Syrdarya basin are expected to decrease by 5\%, and in the Amudarya basin - by $15 \%$. The total water deficit in Uzbekistan until 2015 amounted to more than 3 billion cubic meters; by 2030, it may reach 7 billion cubic meters, and by 2050 - 15 billion cubic meters.

IPC application regardless of natural conditions:

treatment of cotton seeds with IPC leads to a decrease in the seed germination period by an average of 4 days. This is facilitated by the IPC moisture retention properties;

due to moisture retention of an anti-filtration above-soil screen based on IPC, the roots of cotton are continuously fed with mineral fertilizers, which leads to accelerated development of cotton;

the use of an anti-seepage screen from IPC leads to a significant decrease in irrigation rates; as a result, waterlogging and crust formation of the soil is excluded, aeration is improved, and soil erosion is prevented;

in the season of harmsal winds, due to stable soil moisture, the loss of ridges decreases. This is one of the reasons for the growth in cotton yields. $[1,2,3,8]$

* Corresponding author: ngadayev@mail.ru 


\section{Methods}

The research was conducted based on generally accepted methods: observations, measurements, and analyzes were used in the manuals "Methods for studying the agrophysical, agrochemical and microbiological properties of soil in cotton fields" and "Methods of field experiments" adopted by PSUEAITI. The representativeness of the field experiment was determined by the method of V.V Shabanov and EP Rudachenko and the utility model software "Determination of changes in soil moisture before and after irrigation based on the use of interpolymer complexes in cotton irrigation" (DGU09575) was used. [4, $6,9,11]$

Field experiments were conducted in 2017-2019 on the fields of the farm "Omad Kelajak Baraka." The area of the experimental field is 1.0 ha, and the area of the control field is 1.1 ha, located near the Angren River. Because these fields are located on the banks of the Angren River, the groundwater level drops to 3-5 m. Observations of groundwater variability during cotton irrigation were conducted across regions. For this, observation wells consisting of a three-piece perforated pipe with a diameter of $0.05 \mathrm{~m}$ and a length of $15 \mathrm{~m}$ were used.

The experimental study consisted of four parts.

In the first part of the study, laboratory experiments were performed to determine the water permeability properties of the anti-filtration screen formed based on the interpolymer complex in Wagner vessels $[14,15]$.

In the second part of the study, in field experiments, interpolymer complex-based screen screens were generated in the first and third sections of screens of different lengths divided into 4 equal parts, and cotton screening was applied using discrete irrigation technology and devoted to observational work.

The third part of the study was conducted based on interpolymer complex-based screens and anti-infiltration underground screens and studied the issues of inefficient use of mineral fertilizers and irrigation water savings.

To apply a polymer - polymer complex solution to the soil surface, a system was used with a slight re-equipment for the introduction of herbicides, installed on a tractor with a seeder for sowing cotton with a flow rate of $0.6-0.81 / \mathrm{m} 2$. The event is carried out simultaneously with spraying with herbicide on the soil surface during cotton sowing and before each irrigation when cutting furrows (see Figure 1) [12-17].
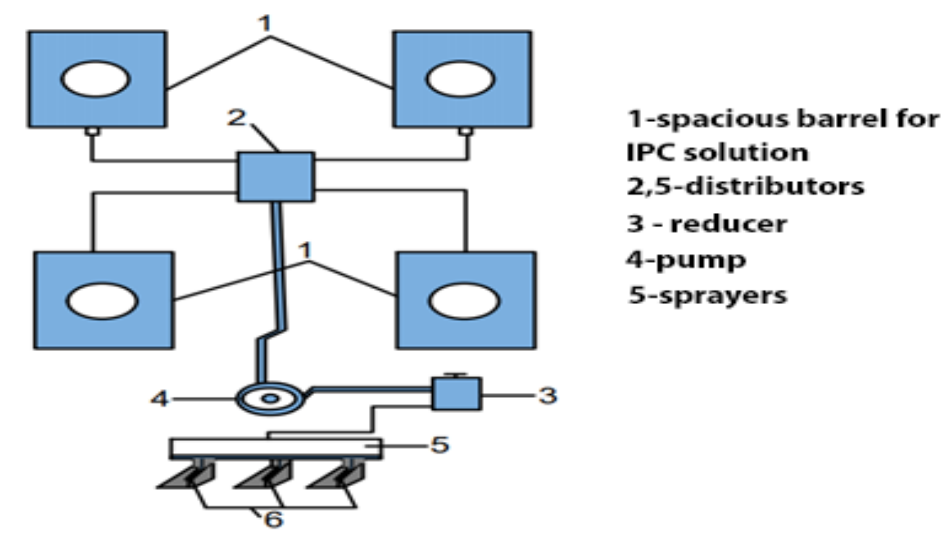

Fig. 1. Scheme of the unit for applying the interpolymer complex 


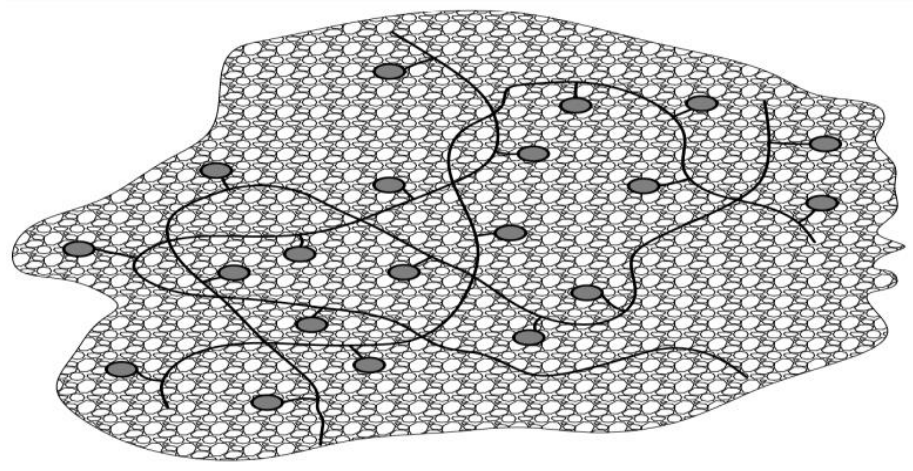

Fig. 2. Interpolymer complex + mineral fertilizer mixture in the process of matrix polycondensation of urea and formaldehyde in the presence of carboxymethylcellulose formation scheme

\section{Results and Discussion}

It is known that the methods of delivery of mineral fertilizers are somewhat complicated, based on traditional methods, which lead to inefficient consumption of large amounts of mineral fertilizers. Experiments have shown that most of the mineral fertilizers applied during the irrigation of cotton are added to the groundwater under irrigation water pressure. One of the proposed methods to reduce the inefficient use of mineral fertilizers based on the grant KXA-7-033-2015 "Reduction of inefficient use of soil mineral fertilizers in cotton irrigation using screens made using the Interpolymer complex" implemented at the Tashkent Institute of Irrigation and Agricultural Mechanization Engineers. .d. Akhmedjanov is covered in the researches of DG [8]. As a continuation of this research, another technology was created based on the above grant. According to him, while in previous studies only interpolymer-based screened screens were used, in our studies, interpolymer complex-based anti-filtration screens and screens were used together. The method of creating an underground screen is widely covered in the research of G.I. Mukhamedov, G. Akhmedjanov [5-10].

There is no doubt that one of the most pressing issues of the day is the effective supply of mineral fertilizers during irrigation to develop and increase the cotton crop while achieving water savings.

According to reliable sources, to grow a cotton crop of 1 ts/ha of cotton, the plant receives from the soil $5.5-6.5 \mathrm{~kg}$ of nitrogen per hectare, $2-2.5 \mathrm{~kg}$ of phosphorus, and $5-6$ $\mathrm{kg}$ of potassium. Regardless of productivity, due to environmental degradation, the cotton plant's demand for mineral fertilizers has been increasing over the years, with nitrogen demand ranging from $69 \%$ (1970) to $72 \%$ (2017), phosphorus consumption from $42 \%$ to $48 \%$, and comparison. Potassium consumption increased 3 times during the phase, i.e., from $35 \mathrm{~kg}$ to $100 \mathrm{~kg}$ per hectare

Studies using Wagner vessels were conducted in experimental and control options. In the experimental vessel, an underground screen based on the interpolymer complex was formed at a depth of $40 \mathrm{~cm}$, and a surface screen was formed on the soil surface with a mixture of $23 \mathrm{~g}$ of nitrogen. In the control variant, $23 \mathrm{~g}$ of mineral (nitrogen) was sprayed at the rate of $320 \mathrm{~kg}$ per hectare. In the second series of experiments, instead of nitrogen, phosphorus mineral was applied at the rate of $225 \mathrm{~kg}$ per hectare (N-320, P-225, K-160). Each option was irrigated with the same amount. According to the results of the study of water absorption rate and filtration time in the soil, when the interpolymer complex + mineral fertilizer-based surface and interpolymer complex-based infiltration screens are 
used together, the irrigation process is up to $38-38.7 \%$ of the total amount of mineral fertilizers in the active soil layer. More survival was observed [18-21].

Table 1. Conducted in Wagner vessels on horizons experimental results

\begin{tabular}{|c|c|c|c|c|c|c|}
\hline \multicolumn{7}{|c|}{ Mineral fertilizers } \\
\hline \multirow[b]{2}{*}{$\begin{array}{l}\text { Layer, } \\
\text { sm }\end{array}$} & \multicolumn{3}{|c|}{$\begin{array}{l}\text { Nitrogen, from the amount transferred } \\
\text { in } \%\end{array}$} & \multicolumn{3}{|c|}{$\begin{array}{l}\text { Phosphorus, from the amount transferred } \\
\text { in } \%\end{array}$} \\
\hline & $\begin{array}{l}\text { Experie } \\
\text { nce }\end{array}$ & Control & $\begin{array}{l}\text { Difference of } \\
\text { mineral } \\
\text { fertilizers in } \\
\text { experimental } \\
\text { and control } \\
\text { containers in } \\
\text { the layer of } 0 \text { - } \\
40 \mathrm{~cm}, \%\end{array}$ & $\begin{array}{l}\text { Experie } \\
\text { nce }\end{array}$ & $\begin{array}{c}\text { Cont } \\
\text { rol }\end{array}$ & $\begin{array}{l}\text { Difference of mineral } \\
\text { fertilizers in } \\
\text { experimental and } \\
\text { control containers in } \\
\text { the layer of } 0 \text { - } 40 \\
\text { cm, } \%\end{array}$ \\
\hline $0-10$ & 16.6 & 3.2 & \multirow{8}{*}{38.3} & 14.3 & 3.2 & \multirow{8}{*}{38.0} \\
\hline $10-20$ & 15.3 & 3.8 & & 13.9 & 3.5 & \\
\hline $20-30$ & 13.5 & 4.7 & & 12.7 & 4.0 & \\
\hline $30-40$ & 10.4 & 5.9 & & 11.2 & 3.4 & \\
\hline $40-50$ & 8.3 & 7.1 & & 9.9 & 7.6 & \\
\hline $50-60$ & 8.5 & 8.3 & & 8.7 & 8.1 & \\
\hline $60-70$ & 8.3 & 9.1 & & 8.4 & 9.2 & \\
\hline $70-100$ & 18.6 & 57.9 & & 20.9 & 61.0 & \\
\hline
\end{tabular}

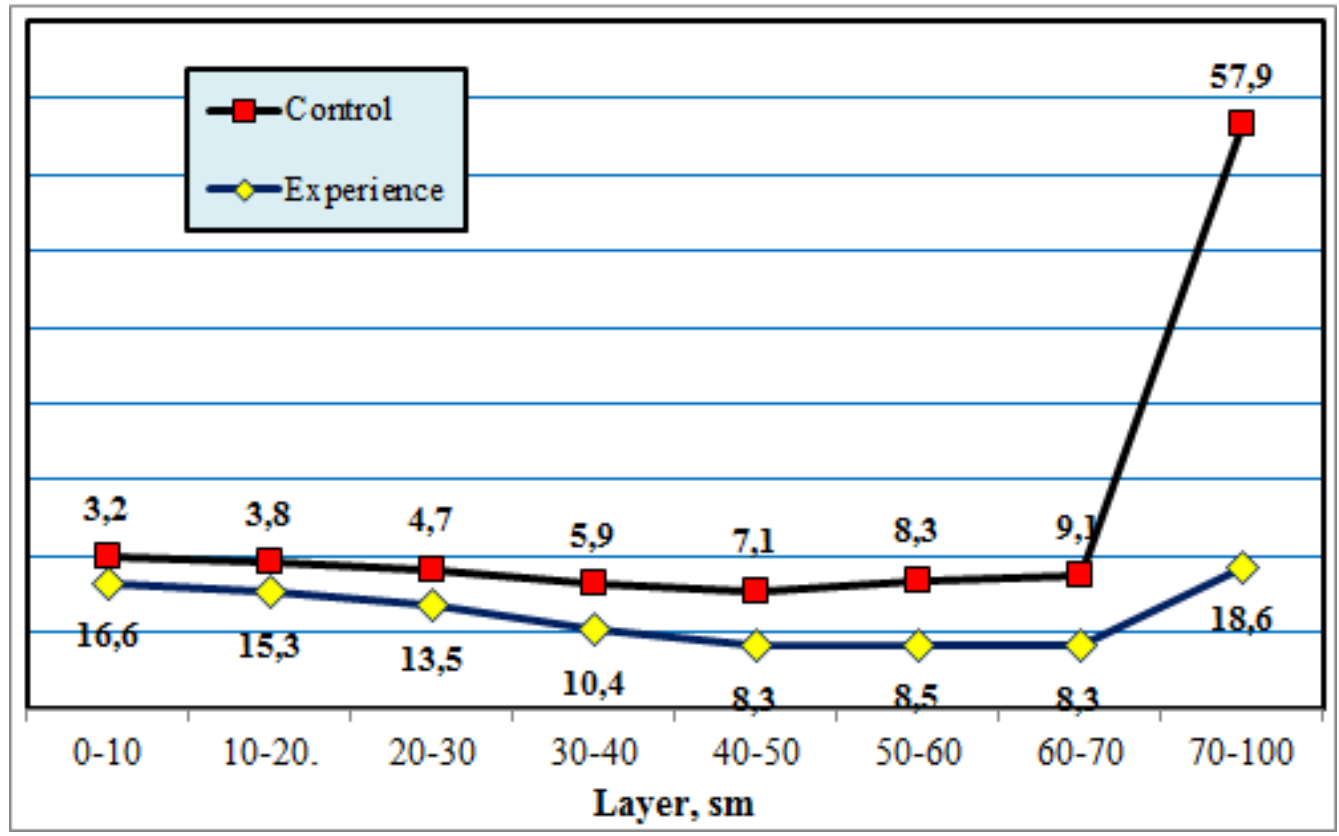




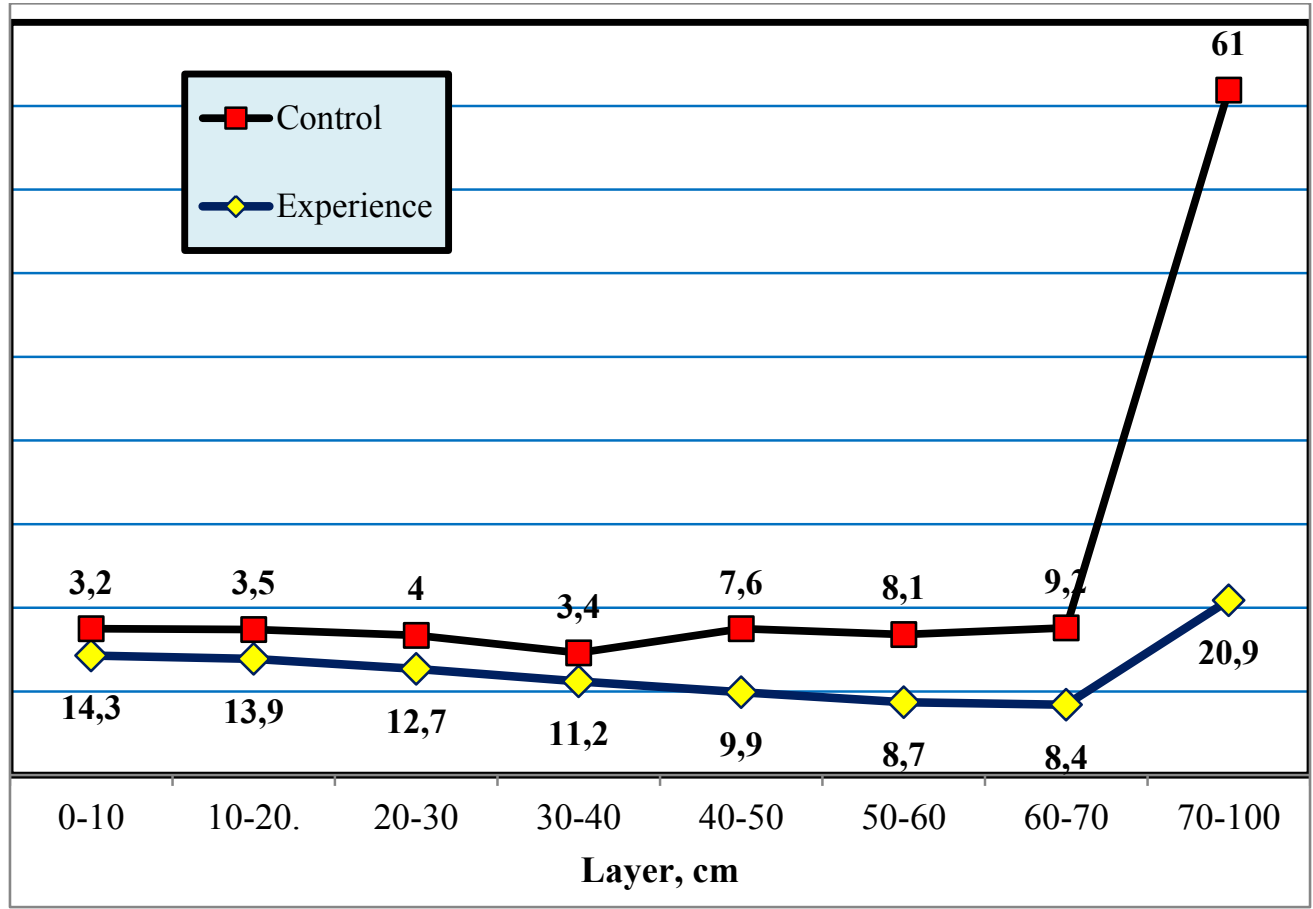

Fig. 2. Difference of nitrogen mineral fertilizers in experimental and control containers, $\%$

Also, according to the results of the analysis conducted at the Research Institute of Soil Science and Agrochemistry, we have managed to reduce the inefficient use of mineral fertilizers (nitrogen and phosphorus) by $38.7 \%$ and $38.5 \%$, respectively. According to the year's results, the yield in the experimental variant increased by an average of 5.3 quintals compared to the control variant and amounted to 43.6 quintals per hectare.

Table 2. Cotton yield and the amount of water consumed per unit of output

\begin{tabular}{|c|c|c|c|c|}
\hline Variants & $\begin{array}{c}\text { Experience } \\
\text { number }\end{array}$ & $\begin{array}{c}\text { Irrigation rate, } \\
\mathrm{m}^{3}\end{array}$ & $\begin{array}{c}\text { Productivity, } \\
\mathrm{s} / \mathrm{ha}\end{array}$ & $\begin{array}{c}\text { Water } \\
\text { spending, } \\
\mathrm{m}^{3} / \mathrm{sent}\end{array}$ \\
\hline $\mathrm{A}$ & Experience & 2377 & 43.6 & 54.5 \\
\hline $\mathrm{S}$ & Control & 3246,9 & 38.3 & 84.7 \\
\hline
\end{tabular}

\section{Conclusions}

Discrete irrigation of cotton from screen (subsoil and surface) plots formed based on interpolymer complexes as a result of irrigation retains $32,0-38,7 \%$ more mineral fertilizers in the active layer of the soil than irrigation from conventional non-screen plots. / was found to be more. The soil at the beginning of the growing season in the experimental field is planted with cotton. The amount of volumetric weight of the layers of $0-30 \mathrm{~cm}, 30-50$ $\mathrm{cm}$ 1.04-1.08 $\mathrm{g} / \mathrm{cm} 3$. By the end of the growing season, when the pre-irrigation moisture in the screen plots was $65-70-65 \%$ relative to the Boundary field moisture capacity, the volume weight of $0-30 \mathrm{~cm}, 30-50 \mathrm{~cm}$ layers of soil was $1.06-1.09 \mathrm{~g} / \mathrm{cm} 3$. The bulk density is $0.02 \mathrm{~g} / \mathrm{cm} 3$ was found to increase. 


\section{References}

1. Ahmedjanov D.G., Beknazarova Z.F., Kasimova U. Biotechnology in agriculture $J$ "Young scientist" Russia 4, pp.31-35, (2015)

2. Allen R.G., Pereira L.S., Raes D., Smith M. Crop Evapotranspiration. Guidelines for Computing Crop Water Requirements FAO Irrig And Drain 56 Rome p.300, (1998)

3. Amemia M.F., Naren N., Gerard C.T., Soil water depletion by irrigated cotton as influenced by water regime of plant development J Agpon pp.366-379.

4. Tsuchida E Interpolymer complexes Characteristics and application Jap Sci Soc Pres pp.322-328, (2003)

5. Fatxulloyev A., Gafarova A., Otakhonov M., Allayorov D. The hydraulic efficiency of the soil channels IOP Conference Series: Materials Science and Engineering 883(1), (2020), 012042 doi:10.1088/1757-899X/883/1/012042.

6. Amanov B.T., Gadaev N.N., Ahmedjonov D.G., Zhaparkulova E. Mathematical calculations of water saving during furrow irrigation of cotton using a screen from an interpolymer complex Journal of Physics: Conference Series 1425(1) 012120, (2020)

7. Nabiollina M Zhaparkulova Y Sherov A Assessment of water resources of the Asa river basin in Southern of Kazakhstan under conditions of climate change. E3S Web of Conferences 176, 04004, (2020)

8. Sherov A., Urinboev S. Innovative technologies in the effective use of water resources. IOP Conference Series: Materials Science and Engineering, 883(1) 012144, (2020)

9. Fatxulloyev A., Abduraimova D., Otakhonov M., Atakulov D., Samiev L. Method designing of open drainages IOP Conference Series: Materials Science and Engineering 883(1), 012047, (2020), doi:10.1088/1757-899X/883/1/012047

10. Sherov A., Soliev B. Protection of recovery projects and developed areas from flooding IOP Conference Series: Materials Science and Engineering 883(1) 012094 , (2020)

11. Ahmedjonov D., Gadaev N., Development of technologies for the economy of polyvinyl water with the application of the screen from the interpolymernogo complex. Science and world Journal. №6(82) pp.42-44, (2020)

12. Fatxulloev A., Gafarova A. Study of the process of cultivation in soil fertile irrigation canals E3S Web of Conferences 97, 05025 (2019), https://doi.org/10.1051/e3sconf/20199705025.

13. Fatkhulloev A., Gafarova A., Hamraqulov J. 2019 The Importance of Mobile Applications in the Use of Standard Water Measurements International Conference on Information Science and Communications Technologies Applications, Trends and Opportunities 9011816, (2019), doi: 10.1109/ICISCT47635.2019.9011816.

14. Gadaev N., Ahmedjonov D., Amanov B., Muxammadeva M., Ergashev I., Study of irrigation characteristics and improvement of irrigation techniques using interpolymer complex-based anti-filtration screen IOP Conf. Series: Materials Science and Engineering 1030 012124, (2020)

15. Sherov A., Amanov B., Gadayev N., Tursunboev Sh., Gafarova A. 2021 Basis of cotton irrigation cultures taking into current natural conditions and water resources (on natural conditions of the Republic of Uzbekistan) IOP Conf. Series: Materials Science and Engineering 1030 012146, (2020), doi:10.1088/1757899X/1030/1/012146.

16. Khudaev I., Muratov O., Turdibekov I., Yusupov M. Technology to restore design parameters of irrigation pump discharge pipelines IOP Conference Series: Materials Science and Engineering 883(1), (2020)

17. Astanakulov K., Karimov M., Khudaev I., Israilova D., Muradimova F. The 
separation of light impurities of safflower seeds in the cyclone of the grain cleaning machine IOP Conference Series: Earth and Environmental Science 614(1), (2020)

18. Arifjanov A., Fatxullaev A. Natural Studies for Forming Stable Channel Sections Journal of Physics: Conference Series 1425(1) 012025, (2020), doi:10.1088/17426596/1425/1/012025.

19. Fatxulloyev A., Allayorov D., Otakhonov M. Study of hydraulic parameters for concreting channels IOP Conference Series: Earth and Environmental Science 614(1) 012054, (2020) doi:10.1088/1755-1315/614/1/012054.

20. Fatxulloyev A., Gafarova A., Hamroqulov J. Improvement of water accounting for irrigation systems IOP Conference Series: Materials Science and Engineering 1030 012145, (2021), doi:10.1088/1757-899X/1030/1/012145.

21. Gulomov S., Sherov A. Study on drip irrigation system as the best solution for irrigated agriculture IOP Conference Series: Earth and Environmental Science 614(1) 012144, (2020) 